Ivan Wallan Tertuliano ${ }^{1}$ Eric Matheus Rocha Lima ${ }^{2}$ Vivian de Oliveira ${ }^{3}$ Vladan Pavlovic ${ }^{4}$ Afonso Antonio Machado ${ }^{5}$ Carlos Norberto Fischer ${ }^{6}$
JEL:E22;M21;M40;L83;M21;C14;C61;D61

DOI: $10.5937 /$ industrija46-16116

UDC: 005.336.1:[796.332:061.23(81)

658.14/.17:796.332

005.332

Original Scientific Paper

\title{
Do financial results influence sports results in football industry? - Case study of the Brazilian football league
}

\author{
Article history: \\ Received: 23 December 2017 \\ Sent for revision: 23 January 2018 \\ Received in revised form: 7 February 2018 \\ Accepted: 7 February 2018 \\ Available online: 20 March 2018
}

Abstract: The purpose of this article is to investigate the influence of club revenues on their classification during the seasons from 2007 to 2016 of the first division of the Brazilian Football League. The data on club revenue and classification presented in this study were obtained on the websites of the clubs, of entities that investigate the sports economy of the Brazilian Football Confederation. In this study, we used information from 16 clubs, which were divided into 3 sample groups, according to the Total Revenue in dollars. The results showed that the G1 group had higher total revenue than the other groups and that the G3 Group had the lowest revenue among the groups, but that all groups evolved during the evaluated years. In relation to the classification, you can see that groups G1 and G2 presented similar results and that the G3 group always occupied the lowest ranked places in the championship. These results demonstrated a correlation between revenue and club classification. These results allow us to conclude that the higherrevenue teams showed better positions in the championship because, by collecting more, they tend to have better conditions to compete for the title

\footnotetext{
${ }^{1}$ Adventist University Center of São Paulo (Unasp) - São Paulo - Brazil

${ }^{2}$ State University at Rio Claro (UNESP) - Rio Claro - Brazil

${ }^{3}$ University Center FIEO - Osasco - Brazil

${ }^{4}$ University of Pristina, Faculty of Economics, Kosovska Mitrovica, Serbia, vladan.pavlovic@pr.ac.rs

${ }^{5}$ São Paulo State University at Rio Claro (UNESP) - Rio Claro - Brazil

${ }^{6}$ São Paulo State University at Rio Claro (UNESP) - Rio Claro - Brazil
} 
Tertuliano W.I., et. al.: Do financial results influence sports results in football industry?

and continue to increase their revenues, not only for awards and sponsorships, but also for exploring their titles.

Keywords: Football, Financial analysis, Brazilian championship, Classification of clubs; Sports administration

\section{Da li finansijski rezultati utiču na sportske rezultate u fudbalskoj industriji? - Studija slučaja Brazilske fudbalske lige}

Apstrakt: Cilj ovog članka je istraživanje uticaja prihoda klubova na njihovo rangiranje. Istraživanje je sprovedeno u prvoj diviziji Brazilske fudbalske lige u periodu od 2007. do 2016. godine. Podaci o prihodima klubova i njihovom rangiranju prikupljeni su sa internet stranica klubova $i$ entiteta koji istražuju sportsku ekonomiju brazilske fudbalske konfederacije. U ovoj studiji koristili smo podatke 16 klubova, koji su, na osnovu ukupnih prihoda, razvrstani u tri grupe. Klubovi svrstani u grupu G1 ostvarili veći ukupni prihod od klubova razvrstanih u ostale grupe, klubovi svrstani u grupu G3 ostvarili su najmanji prihod, ali je istraživanje pokazalo da su klubovi iz sve tri grupe evoluirale tokom posmatranih godina. Posmatrajući rangiranje klubova, uočava se da su klubovi svrstani u grupu G1 i G2 ostvarile slične rezultate, a da su klubovi svrstani u grupu G3 uvek zauzimali najnižu poziciju u prvenstvu. Ovi rezultati potvrđuju korelaciju između ostvarenih prihoda i rangiranja kluba. Može se izvesti zaključak da su kubovi sa većim prihodima osvajali bolje pozicije na prvenstvu,budući da veći prihodi omogućavaju bolje uslove za takmičenje za titulu, a dalje povećanje prihoda posledica je, ne samo, primljenih nagrada $i$ sponzorstva, već takođe i posledica osvojenih titula.

Ključne reči: fudbal, finansijska analiza, brazilsko prvenstvo, rangiranje klubova; upravaljanje u sportskim društvima

\section{Introduction}

Having become one of the highly propulsive industries, football turned out to be more than a sport (Pavlović, Mijatović, \& Mllačić, 2013). Currently, football institutions are not simple sport organizations, they have become big companies with revenues generated by stadium tickets, sponsors, transfers, TV rights, among others (Ribeiro \& Lima, 2012). In this line, Soriano (2013) adds that the three main sources of revenue are: stadium, TV rights and 
marketing. About the first one, Soriano (2013) highlights the importance of the tourists for the clubs, because they might be interested in watching some game during their trips. About TV rights, reinforces that the biggest profits are taken by contracts involving international tournaments. Finally, about the marketing, he recommends a few, but big sponsors, besides highlighting the relevance of pre-season tournaments to raise clubs image in other countries. The amount of commercial revenue is largely conditioned by players from the primary market, and it should be borne in mind that only planetary clubs can make full use of the potential marketing effect of players who are global stars (Pavlović, Ljumović, \& Knežević, 2014, p. 234).

In Brazil, those collection ways are also present. For example, in 2011, the 20 clubs with the biggest revenue generated total revenue which was $27 \%$ higher than total revenue generated in 2010 , resulting in $R \$ 2,14$ billion (BDO, 2012). In theory, today, football clubs certainly focus on both financial and sports success (Mijatović, Pavlović, \& Mllačić, 2015, p. 146). However, there is still no unified perspective on a primary measure of success in football. (Ibid) However, achieving triumphs and balancing the finances is a complex task, but that seems to be of higher likelihood to achieve by the richest clubs, since they have bigger facility to collect money and invest it in a qualified manner. Of course, rich clubs can contract more expensive transfers (see: Pavlović, Milačić, \& Ljumović, 2014) and bring better players, which in the case of planetary clubs will results in higher commercial revenues and better sports success. According to Anderson \& Sally (2013), at the same way the rich countries specialize themselves in complex products, rich football teams invest more capital and technologies in their teams, besides practicing a kind of play that the small clubs cannot do. According to same authors, rich clubs invest in database and information technology, besides investing in equipment to structure trainings, physical conditioning and rehabilitation. So, this article justifies itself based on the fact that the football clubs represent a kind of business that aims to achieve the success and the good financial situation (Guzmán, 2006). However, Haas, Kocher \& Slitter (2004) argue that even though the success is more relevant than the financial situation, there is a strong correlation between the terms. Because of this imbalance (investments, revenues and success) present also in the Brazilian Football League, this article aims to understand how the ways of source can affect clubs performance in a sequence of seasons. With the aforementioned in mind, the objective of this study consists of an investigation of the revenue influence in clubs classification from season 2007 to season 2016 of the first division of the Brazilian Football League (Serie A). 
Tertuliano W.I., et. al.: Do financial results influence sports results in football industry?

\section{Research methodology}

To meet the objective of this study, the research method "explanatory documentary research" was used. Explanatory documentary research is a type of study that tries to identify, record, analyze and interpret facts and their causes (Lakatos \& Marconi, 2011). Club revenue data, presented in this study, were obtained on the Internet, accessing sites that present such information. These websites are: Globoesporte (Barros, 2017; CORINTHIANS..., 2011; Gonçalves, 2012; Mará, 2015; Venancio, 2014), Lance (Somoggi, 2017a, 2017b), Slide Share (Somoggi, 2017c), ESPN (DÍVIDAS..., 2016). In this study, the club's revenue was represented by the club's total collection amounts related to TV rights, games box office, sponsors, player marketing, sporting goods sales, membership fees, among others. In order to relate the team's revenue (represented by their total collection between 2007 and 2016) and their performance in the national league of the first division (final classification in the championship evaluated), the final classification data of the clubs were used in the first division of the Brazilian League between 2007 and 2016. This information was found on the website of the Brazilian Football Confederation (CBF), the institution responsible for football in Brazil (http://www.cbf.com.br/competicoes/). It should be noted that the first division of the Brazilian Football League consists of 20 clubs, thus, one of the limitations of the expansion of the participating clubs in the present study. In addition, in order to select the clubs, information on club revenue should be available for all evaluated years, which has not occurred with all clubs in the first survey. Thus, after collecting all data on club revenue, the total number of clubs used was 16 , as 4 clubs presented missing data and were excluded from the analyzes to avoid compromising results. The 16 clubs were divided into three groups, according to their total revenue (in millions of dollars) between 2007 and 2016 (Table 1). Thus, the 3 research groups were formed as follows: Group 1: that had total revenue, between 2007 and 2016, between 600 and 800 million dollars (5 clubs); Group 2: Teams that had total revenue, between 2007 and 2016, between 300 and 5500 million dollars (7 clubs); and Group 3: Teams that had total revenue, between 2007 and 2016, between 130 and 280 million dollars (4 clubs).

This study shows descriptive and inferential analysis, also applying intragroup and between groups analysis. The analysis were conducted according to study's objective, that is to investigate the influence of clubs revenues in their final results from season 2007 to season 2016 of the first division of Brazilian Football League. The inferential analyzes were used because the descriptive statistics are not sufficient to give meaning to the findings, since it does not have the "power" of comparison that mathematics has and therefore cannot give meaning to its findings, as well as the inferential statistics can. Thus, it is necessary to use inferential statistics, since it can demonstrate if there is a 
significant difference and, consequently, a causal difference $(p<0.05)$ and not a casual difference. In this study the number of participants used was less than 30, that was needed to test the normality and the hegemony of variance (Green, Salkind, \& Akey, 2000). To test the normality the KolmogorovSmirnov test (K-S) was used, and to test the hegemony of variance, the Levene test was used. Regarding normality, K-S test showed $p>0,05$, that is normality in the investigated variances. Regarding hegemony of variance, Levene test showed $p>0,05$, which demonstrates that there is hegemony of variance (Field, 2009). Through these results, data normality was assumed and the alpha value 0,05 was used to significant differences. In between groups analysis, the Anova One Way test was used and in the intragroup analysis the Anova one-way was used, with repeated measure in the last factor and Pearson Correlation. When intragroup and between group significant differences were found, post hoc tests were conducted. To control of the mistake type 1, the sequential procedure Holm de Bonferroni was used (Green et al., 2000). All inferential analysis were made with the support of the IBM SPSS Statistics, version 20.

Table 1. Teams and their yearly collection $(n=16)$, in million Reais

\begin{tabular}{|c|c|c|c|c|c|c|c|c|c|c|c|c|}
\hline GROUP & TEAM & $\begin{array}{l}\text { Total } \\
\text { revenue } \\
2016\end{array}$ & $\begin{array}{l}\text { Total } \\
\text { revenue } \\
2015\end{array}$ & $\begin{array}{c}\text { Total } \\
\text { revenue } \\
2014\end{array}$ & $\begin{array}{l}\text { Total } \\
\text { revenue } \\
2013\end{array}$ & $\begin{array}{c}\text { Total } \\
\text { revenue } \\
2012\end{array}$ & $\begin{array}{c}\text { Total } \\
\text { revenue } \\
2011\end{array}$ & $\begin{array}{c}\text { Total } \\
\text { revenue } \\
2010\end{array}$ & $\begin{array}{c}\text { Total } \\
\text { revenue } \\
2009\end{array}$ & $\begin{array}{l}\text { Total } \\
\text { revenue } \\
2008\end{array}$ & $\begin{array}{c}\text { Total } \\
\text { revenue } \\
2007\end{array}$ & \begin{tabular}{|c|} 
Total \\
revenue \\
$2016-$ \\
2007
\end{tabular} \\
\hline \multirow{5}{*}{ G1 } & Corinthians & 142,8 & 87,8 & 75,9 & 92,9 & 105,4 & 85,4 & 62,5 & 53,2 & 31,4 & 39,6 & 777,0 \\
\hline & Flamengo & 150,0 & 104,6 & 102,1 & 80,3 & 62,4 & 54,4 & 37,8 & 35,3 & 34,7 & 26,3 & 687,8 \\
\hline & São Paulo & 115,7 & 97,3 & 75,1 & 107,3 & 83,6 & 66,5 & 57,6 & 51,4 & 46,5 & 55,9 & 756.7 \\
\hline & Internacional & 86,1 & 87,4 & 65,1 & 81,4 & 77,7 & 58,3 & 58,9 & 51,8 & 39,1 & 45,8 & 651,6 \\
\hline & Palmeiras & 146,4 & 103,4 & 72,8 & 53,3 & 71,9 & 43,6 & 43,6 & 36,8 & 39,6 & 25,4 & 636.7 \\
\hline \multicolumn{2}{|l|}{$\begin{array}{l}\text { TOTAL } \\
\end{array}$} & 640,9 & 480,4 & 391,1 & 415,1 & 401,0 & 308,2 & 260,4 & 228,5 & 191,1 & 192,9 & $3509,7^{\star}$ \\
\hline \multicolumn{2}{|l|}{ AVERAGE } & 128,2 & 96,1 & 78,2 & 83,0 & 80,2 & 61,6 & 52,1 & 45,7 & 38,2 & 38,6 & $701,9^{\star \star}$ \\
\hline \multirow{7}{*}{ G2 } & Grêmio & 91,9 & 56,1 & 63,6 & 56,6 & 68,7 & 42,1 & 33,4 & 32,6 & 25,7 & 32,1 & 502,9 \\
\hline & Cruzeiro & 70,1 & 107,0 & 65,6 & 55,3 & 35,4 & 37,9 & 29,8 & 35,7 & 27,6 & 22,8 & 487,2 \\
\hline & Santos & 87,0 & 50,0 & 50,0 & 56,0 & 58,2 & 55,6 & 34,3 & 20,7 & 19,2 & 15,6 & 446,5 \\
\hline & Atlético-MG & 93,0 & 71,9 & 52,6 & 67,0 & 47,9 & 29,4 & 27,4 & 19,4 & 16,9 & 17,1 & 442,9 \\
\hline & Vasco & 62,7 & 55,8 & 38,0 & 47,0 & 43,0 & 40,3 & 24,6 & 24,9 & 15,3 & 15,0 & 366,6 \\
\hline & Fluminense & 86,2 & 53,0 & 36,0 & 36,7 & 44,5 & 23,6 & 22,6 & 18,0 & 19,5 & 11,6 & 351,6 \\
\hline & Atlético-PR & 53,2 & 46,5 & 45,5 & 21,6 & 62,6 & 19,3 & 19,9 & 18,5 & 13,0 & 15,9 & 316,0 \\
\hline \multicolumn{2}{|l|}{ TOTAL } & 544,2 & 440,3 & 351,4 & 340,1 & 360,3 & 248,1 & 192,0 & 169,9 & 137,4 & 130,1 & $2913,7^{*}$ \\
\hline \multicolumn{2}{|l|}{ AVERAGE } & 77,7 & 62,9 & 50,2 & 48,6 & 51,5 & 35,4 & 27,4 & 24,3 & 19,6 & 18,6 & $416,2^{\star \star}$ \\
\hline \multirow{4}{*}{ G3 } & Botafogo & 45,9 & 35,6 & 40,1 & 45,4 & 36,1 & 17,3 & 15,5 & 13,5 & 15,1 & 12,1 & 276,7 \\
\hline & Coritiba & 32,2 & 25,2 & 25,7 & 28,4 & 25,4 & 19,6 & 9,0 & 12,1 & 11,1 & 4,4 & 193,1 \\
\hline & Vitória & 32,9 & 15,4 & 18,2 & 19,1 & 15,4 & 10,1 & 12,4 & 8,9 & 5,5 & 3,6 & 141,4 \\
\hline & Goiás & 26,6 & 22,2 & 19,6 & 16,3 & 14,3 & 5,0 & 8,9 & 8,9 & 6,1 & 11,7 & 139,6 \\
\hline \multicolumn{2}{|l|}{ TOTAL } & 137,6 & 98,3 & 103,6 & 109,3 & 91,2 & 52,0 & 45,8 & 43,4 & 37,8 & 31,7 & 750,8 \\
\hline \multicolumn{2}{|l|}{ AVERAGE } & 34,4 & 24,6 & 25,9 & 27,3 & 22,8 & 13,0 & 11,5 & 10,9 & 9,4 & 7,9 & $187,7^{* *}$ \\
\hline
\end{tabular}

* In trillion of dollars. ${ }^{*}$ Average Revenue for the period 2016-2007.

Source: sites used in the study 
Tertuliano W.I., et. al.: Do financial results influence sports results in football industry?

\section{Literature review}

The financial and accounting aspects of the football industry have been in the focus of numerous recently published papers, which is the consequence of rising interest in these topics all over the world. Additionally, numerous researchers investigate the correlation between the financial and sport successes of the football clubs, as well as the impact of sport and financial successes on the clubs stock value. Different technics has been used for the analyses of the football clubs efficiently and different results have been obtained (See: Barajas, Fernández-Jardón, \& Liz, 2005; C. P. Barros, Garciadel-Barrio, \& Leanch, 2009; Espitia-Escuer \& García-Cebrián, 2010; Guzmán, 2006; Haas et al., 2004; Jardin, 2009; Mijatović et al., 2015; Pyatunin et al., 2016; Ribeiro \& Lima, 2012; Samagaio, Couto, \& Caiado, 2009; SoleimaniDamaneh, Hamidi, \& Sajadi, 2011). The most part of these papers did not take into account the effects of the crises on the financial success of the analyzed clubs (See more in: Filipović \& Miljković, 2014), neither the uses of different accounting treatment of the transfer fee on the financial success (see more in: Amira \& Livne, 2005; Borré \& Gelmini, 2008; Morrow, 1999; Pavlović, Ljumović, et al., 2014; Rowbottom, 2002).

\section{Results description}

Given the sample, the present study can be considered as a case study. Thus, it must be considered that, in itself, as a case study, the results of it apply only to the clubs and the context involved, thus limiting their power of generalization. Firstly, revenue groups were analyzed, verifying the differences between groups. In a qualitative analysis, it was observed that G1 had the highest revenue in all analyzed years (2007 to 2016), which was expected, since this group contains the clubs with highest revenues. This information was confirmed because results showed significant differences between groups $(p<0,01)$. Regarding differences location, the Bonferroni post hoc test showed significant differences in all years and between all groups. G1 had higher revenues than G2 and G3, with G2 having higher values than $G 3$ in a significant way $(p<0,05)$. These data suggest that $G 1$ clubs, in all years analyzed, show a higher revenue and this information may be explained by the bigger media exposure of this teams in their respective matches. Regarding the groups revenue evolution, an intragroup analysis was conducted, using the Anova one-way test with repeated measures at the last factor. From the results obtained by a qualitative analysis, it can be seen that G1 presented a higher revenue year-by-year (table 1). This information was confirmed, because the inferential test presented significant differences to G1 $[F(2,07 ; 8,26)=19,372 ; p<0,001]$. Regarding the difference location, the post 
hoc Bonferroni test only showed significant difference between 2015 (higher revenue) and $2008(p<0,006)$, which demonstrates a gradative revenue evolution. For G2, the same revenue evolution dynamics could be observed, the revenues were rising year-by-year (table 1). Those values were confirmed because the inferential test showed significant differences for G2 [F (2,70; $16,20)=24,920 ; p<0,001]$. Regarding the difference location, the Bonferroni post hoc test presented significant differences between the years 2016, 2015, 2014 and 2012 and the years 2007, 2008 and 2009. These differences suggest that the revenue of G2 evolved gradually because the differences were only between the extremes, something close to what happened with G1. Regarding G3, using the qualitative analysis, it can be seen that the revenue evolved until 2013, dropped in 2014 and raised once more in 2016 (table 1). These results suggest that in 2014 and in 2015 the clubs had troubles to collect money to their revenue, which can be related with the team's league table position. These values were confirmed, because the inferential test presented significant differences to $G 3[F(1,94 ; 5,81)=15,571 ; p<0,005]$. Regarding the difference location, the Bonferroni post hoc test presented significant difference between 2007 and 2010 and the three last years (2016 to 2013). These values suggest that clubs revenue were very similar, which did not show significant differences among sequential years, only between the extremes.

Table 2 - Occupation of analysis groups (G1, G2 e G3) in categories of Brazilian Série $A(n=16)$

\begin{tabular}{|c|c|c|c|c|c|c|c|c|c|c|c|c|}
\hline Group & Category & $\begin{array}{c}\text { League } \\
\text { Table } \\
\text { Série A } \\
2016 \text { in } \\
\%\end{array}$ & $\begin{array}{c}\text { League } \\
\text { Table } \\
\text { Série A } \\
2015 \text { in } \\
\%\end{array}$ & $\begin{array}{c}\text { League } \\
\text { Table } \\
\text { Série A } \\
2014 \text { in } \\
\%\end{array}$ & $\begin{array}{c}\text { League } \\
\text { Table } \\
\text { Série A } \\
2013 \text { in } \\
\%\end{array}$ & $\begin{array}{c}\text { League } \\
\text { Table } \\
\text { Série A } \\
2012 \text { in } \\
\%\end{array}$ & $\begin{array}{c}\text { League } \\
\text { Table } \\
\text { Série A } \\
2011 \text { in } \\
\%\end{array}$ & $\begin{array}{c}\text { League } \\
\text { Table } \\
\text { Série A } \\
2010 \text { in } \\
\%\end{array}$ & $\begin{array}{c}\text { League } \\
\text { Table } \\
\text { Série A } \\
2009 \text { in } \\
\%\end{array}$ & $\begin{array}{c}\text { League } \\
\text { Table } \\
\text { Série A } \\
2008 \text { in } \\
\%\end{array}$ & $\begin{array}{c}\text { League } \\
\text { Table } \\
\text { Série A } \\
2007 \text { in } \\
\%\end{array}$ & Average \\
\hline \multirow{4}{*}{ G1 } & Elite & 40,00 & 40,00 & 60,00 & & 20,00 & 40,00 & 20,00 & 60,00 & 40,00 & 40,00 & $40,00^{*}$ \\
\hline & $\begin{array}{l}\text { Continental } \\
\text { Competition }\end{array}$ & 40,00 & 40,00 & 20,00 & 40,00 & 40,00 & 40,00 & 60,00 & 40,00 & 40,00 & 20,00 & 38,00 \\
\hline & Neutral & & 20,00 & 20,00 & 40,00 & 20,00 & 20,00 & 20,00 & & & 20,00 & 22,86 \\
\hline & $\begin{array}{c}\text { Relegation } \\
\text { + série B }\end{array}$ & 20,00 & & & 20,00 & 20,00 & & & & 20,00 & 20,00 & 20,00 \\
\hline \multirow{4}{*}{ G2 } & Elite & 28,60 & 28,60 & 14,30 & 42,90 & 42,90 & 28,60 & 42,90 & 14,30 & 28,60 & 28,60 & 30,03 \\
\hline & $\begin{array}{l}\text { Continental } \\
\text { Competition }\end{array}$ & 28,60 & 42,90 & 71,40 & 28,60 & 42,90 & 14,30 & 28,60 & 28,60 & & 57,10 & $38,11^{\star}$ \\
\hline & Neutral & 28,60 & 14,30 & & 14,30 & & 42,90 & 28,60 & 42,90 & 57,10 & 14,30 & 30,38 \\
\hline & $\begin{array}{c}\text { Relegation } \\
\text { + série B }\end{array}$ & 14,30 & 14,30 & 14,30 & 14,30 & 14,30 & 14,30 & & 14,30 & 14,30 & & 14,30 \\
\hline \multirow{4}{*}{ G3 } & Elite & & & & 25,00 & & & & & & & 25,00 \\
\hline & $\begin{array}{l}\text { Continental } \\
\text { Competition }\end{array}$ & 25,00 & & & 50,00 & 25,00 & 50,00 & 25,00 & 25,00 & 100,00 & 25,00 & 40,63 \\
\hline & Neutral & 50,00 & 25,00 & 50,00 & 25,00 & 25,00 & & & 50,00 & & 25,00 & 35,71 \\
\hline & $\begin{array}{l}\text { Relegation } \\
\text { + série B }\end{array}$ & 25,00 & 75,00 & 50,00 & & 50,00 & 50,00 & 75,00 & 25,00 & & 50,00 & $50,00^{*}$ \\
\hline
\end{tabular}

* Category of bigger occupation of clubs, for each group.

Source: Authors' calculations 
In summary, the results demonstrated that the 3 groups increased their revenue, but $\mathrm{G} 1$ was the one with the highest improvement, once compared with the other group's average, suggesting that this group, for having the highest revenue, should occupy the best places on league table. So, to compare the revenue with the league table position, we analyzed the groups in relation to their final position in the tournament (categories). For this, we used the following ranking logic. The top- 4 was classified as "Elite". From $5^{\circ}$ to $10^{\circ}$, clubs were put into the category "Continental Competition". From $11^{\circ}$ to $16^{\circ}$, clubs were classified as "Neutral". From $17^{\circ}$ to $20^{\circ}$, clubs were classified as "Relegation + Série B, according to Table 2 .

According to table 2, it can be observed that G1 had the majority of its clubs in the "Elite" group between 2007 and 2016, presenting 40\% of clubs, in average, in the Brazilian League's top-4. Regarding G2, clubs of this group were, in majority, in the category "Continental Competition" $(38,11 \%)$. About G3, as it was expected, for being the clubs with the lowest revenue in the tournament, which can affect the performance, $50 \%$ of the clubs, in average, finished in the "Relegation + Série B" category. It can also be seen that G1 was the group with less participants in the category "Relegation + Série B", $50 \%$ of the seasons, while G2 and G3 had $80 \%$, showing that a higher revenue contributes to taking better positions on the tournament. Added to this, it's possible to see that $\mathrm{G} 1$ has, in average, $78 \%$ of its clubs in the Brazilian League top-10, demonstrating once more, the relevance of a higher revenue on teams league table position. On the other hand, G3 had $89,29 \%$ of its teams in categories "Neutral" or "Relagation + Série B" on investigated tournaments, showing that a low revenue might compromise team's position on league table. However, since one of the aims of this study was to investigate team's evolution along the seasons, the classification variables were transformed through the following criteria: "Elite" teams received value 4 , "Continental Competition" teams received value 3, "Neutral" ones, value 2, "Relegation + Série B", value 1, as Table 3 shows.

Regarding club's evolution through the tournaments, the results demonstrated that there is no difference between $\mathrm{G} 1$ and $\mathrm{G} 2$, but there is a difference between $G 1$ and $G 3$ in years 2009, 2014 and $2015(p<0,015)$ and between G2 and $G 3$ in 2010 and 2015 ( $p<0,028)$. These results suggest that $G 1$ and G2 present similar classification dynamics in the Brazilian League. In other words, even with different revenue, they present regular positions on the league table, since significant differences were not detected among the groups concerning this variable (classification), in the analyzed period (2007 to 2016). However, G3 presented worse positions in 2009, 2010, 2014 and $2015,40 \%$ of the tournaments considered. These results can be explained by the found numbers regarding clubs revenue, since lower revenue were related to worse positions on league table. 
Tertuliano W.I., et. al.: Do financial results influence sports results in football industry?

Table 3-Clubs classification regarding the category they belong to $(n=16)$

\begin{tabular}{|c|c|c|c|c|c|c|c|c|c|c|c|}
\hline GROUP & CLUB & $\begin{array}{l}\text { CLASSIFI } \\
\text { CATION } \\
\text { SÉRIE A } \\
2016\end{array}$ & $\begin{array}{l}\text { CLASSIFIC } \\
\text { ATION } \\
\text { SÉRIE A } \\
2015\end{array}$ & $\begin{array}{l}\text { CLASSIFIC } \\
\text { ATON } \\
\text { SÉRIE A } \\
2014\end{array}$ & $\begin{array}{l}\text { CLASSIFIC } \\
\text { ATION } \\
\text { SÉRIE A } \\
2013\end{array}$ & $\begin{array}{l}\text { CLASSIFIC } \\
\text { ATION } \\
\text { SÉRIE A } \\
2012\end{array}$ & $\begin{array}{l}\text { CLASSIFIC } \\
\text { ATION } \\
\text { SÉRIE A } \\
2011\end{array}$ & $\begin{array}{l}\text { CLASSIFIC } \\
\text { ATON } \\
\text { SÉRIE A } \\
2010\end{array}$ & $\begin{array}{l}\text { CLASSIFIC } \\
\text { ATION } \\
\text { SÉRIE A } \\
2009\end{array}$ & $\begin{array}{l}\text { CLASSIFIC } \\
\text { ATION } \\
\text { SÉRIE A } \\
2008\end{array}$ & $\begin{array}{l}\text { CLASSIFIC } \\
\text { ATION } \\
\text { SÉRIE A } \\
2007\end{array}$ \\
\hline \multirow{5}{*}{ G1 } & Corinthians & 3,00 & 4,00 & 4,00 & 3,00 & 3,00 & 4,00 & 4,00 & 3,00 & 1,00 & 1,00 \\
\hline & Flamengo & 4,00 & 2,00 & 3,00 & 2,00 & 2,00 & 4,00 & 2,00 & 4,00 & 3,00 & 4,00 \\
\hline & São Paulo & 3,00 & 4,00 & 4,00 & 3,00 & 4,00 & 3,00 & 3,00 & 4,00 & 4,00 & 4,00 \\
\hline & Internacional & 1,00 & 3,00 & 4,00 & 2,00 & 3,00 & 3,00 & 3,00 & 4,00 & 3,00 & 2,00 \\
\hline & Palmeiras & 4,00 & 3,00 & 2,00 & 1,00 & 1,00 & 2,00 & 3,00 & 3,00 & 4,00 & 3,00 \\
\hline \multirow{7}{*}{ G2 } & Grêmio & 3,00 & 4,00 & 3,00 & 4,00 & 4,00 & 2,00 & 4,00 & 3,00 & 4,00 & 3,00 \\
\hline & Cruzeiro & 2,00 & 3,00 & 4,00 & 4,00 & 3,00 & 2,00 & 4,00 & 4,00 & 4,00 & 3,00 \\
\hline & Santos & 4,00 & 3,00 & 3,00 & 3,00 & 3,00 & 3,00 & 3,00 & 2,00 & 2,00 & 4,00 \\
\hline & Atlético-mg & 4,00 & 4,00 & 3,00 & 3,00 & 4,00 & 2,00 & 2,00 & 3,00 & 2,00 & 3,00 \\
\hline & Vasco & 1,00 & 1,00 & 1,00 & 1,00 & 3,00 & 4,00 & 2,00 & 1,00 & 1,00 & 3,00 \\
\hline & Fluminense & 2,00 & 2,00 & 3,00 & 2,00 & 4,00 & 4,00 & 4,00 & 2,00 & 2,00 & 4,00 \\
\hline & Atlético-PR & 3,00 & 3,00 & 3,00 & 4,00 & 1,00 & 1,00 & 3,00 & 2,00 & 2,00 & 2,00 \\
\hline \multirow{4}{*}{ G3 } & Botafogo & 3,00 & 1,00 & 1,00 & 4,00 & 3,00 & 3,00 & 3,00 & 2,00 & 3,00 & 3,00 \\
\hline & Coritiba & 2,00 & 2,00 & 2,00 & 2,00 & 2,00 & 3,00 & 1,00 & 1,00 & 3,00 & 1,00 \\
\hline & Vitória & 2,00 & 1,00 & 1,00 & 3,00 & 1,00 & 1,00 & 1,00 & 2,00 & 3,00 & 1,00 \\
\hline & Goiás & 1,00 & 1,00 & 2,00 & 3,00 & 1,00 & 1,00 & 1,00 & 3,00 & 3,00 & 2,00 \\
\hline
\end{tabular}

Source: Authors' calculations

Intragroup analysis was also conducted, using the Anova one-way test with repeated measures on last factor. Qualitative information, based on table 2 were supported because the inferential test did not show significant differences to $\mathrm{G} 1[\mathrm{~F}(2,49 ; 9,98)=0,867 ; p>0,472]$. It means that $\mathrm{G} 1$ teams, in majority of the analyzed years were inside "Elite" group, corroborating with the qualitative analysis. These numbers suggest that revenue evolution kept G1 in the best positions of the league. Regarding G2, the same analysis was conducted. In this case, the qualitative analysis was also supported by the inferential test $[F(2,34 ; 14,01)=0,689 ; p>0,540]$. In other words, there was no significant difference among the years investigated, demonstrating that G2 teams were, with more frequency on category "Continental Competition". These results suggest that even raising the revenue, G2 teams did not achieve best positions on league table, just maintained the positions of the previous years. Analyzing G3, the inferential test did not present significant differences among the studied years $[F(2,31 ; 6,93)=2,619 ; p>0,139]$. In other words, even rising the revenue, clubs could not improve their positions on Brazilian League table and many were relegated to the lower division. In order to correlate revenue and league table position, Pearson correlation was used. At this point, the values of $R>0,700$ (positive or negative) were considered to accept the correlation. The values used were the ones transformed in the previous analysis. The correlation analysis was conducted between the same year (ex. Revenue 2016 x League table position 2016), 
with the objective to test the hypothesis that the revenue are related to team's classification. Regarding G1, which obtained average 3,00 to the categories, according to Pearson correlation, the results demonstrated strong correlation between total revenue in 2016 and the league table position at the same year on "Elite" group $(r=0,934, p<0,20)$. In other words, the higher revenue of 2016 contributed, to significant extent, to $\mathrm{G} 1$ teams finishing the league inside the Elite Group. Furthermore, the correlation exists also in $2013(r=0,960$, $p<0,009), 2010(r=0,814, p<0,094)$ and $2008(r=0,827, p<0,084)$. These correlations corroborate, partially, with the hypothesis that the clubs with higher revenue occupy the best positions of the tournament, since the Pearson test showed strong correlation in only 4 of the 10 years analyzed. However, into a qualitative analysis, G1 was the group that participated most on "Elite" group (40\%), giving details that teams with higher revenue achieve best positions on league table, in majority. So, intragroup analysis to league table positions demonstrated that G1 has always been in the top-4 of the Brazilian league, which can explain the low correlation, since this group did not have significant decreases on league table. Regarding G2, results demonstrated only correlation at $2008(\mathrm{r}=0,898, \mathrm{p}<0,006)$. In other words, only at this year G2 clubs, in majority, made part of "Neutral" category $(57,10 \%$ of the clubs). To the remaining years there was no correlation between the intermediary revenue and the league table position ("Continental Competition" and "Neutral"), since the average for G2 was 2,83 for the categories. These values suggest that G2 teams oscillated its league position, even increasing their revenue they did not achieve better positions in the tournament, corroborating the intragroup analysis on league table positions, but not corroborating the hypothesis of relation between revenue and better league position. Finally, G3 showed a category average of 1,98 and, as correlation, it was the group which presented more strong correlations in the investigated years. The results demonstrated strong correlations for the years: $2016(r=0,965, p<0,035), 2012(r=0,999, p<0,001), 2011(r=0,942, p<$ $0,058), 2010(r=0,859, p<0,141)$ and $2007(r=0,912, p<0,088)$. These correlations confirm the mentioned hypothesis for this analysis that the clubs with lower revenues present lower positions in the tournament, since G3 showed itself in $50 \%$ of the seasons inside the category "Relegation + Série B".

In summary, the correlation results were able to partially explain the hypothesis. In other words, regarding the hypothesis that clubs with higher revenue get best positions in the Brazilian league, there were only significant correlations to $\mathrm{G} 1$ in $40 \%$ of the analysis. In addition, Pearson correlation test demonstrated that clubs with lower revenues are the clubs that occupy the worst places in the league and in some cases plays the lower division $(50 \%$ of the analysis), partially corroborating the hypothesis that the relation between revenue and league table position exists. 
Tertuliano W.I., et. al.: Do financial results influence sports results in football industry?

\section{Discussion}

Following the objective of the study which was to investigate the club's revenue influence in their final results from season 2007 to 2016 of the first division of Brazilian Football League, the aim was to discuss the obtained results to improve the understanding of the found information. In summary, the results presented in this article demonstrate that all groups increased their revenue, but G1 was the one which showed higher revenue increase, suggesting that this group should occupy the best positions in the league, which actually happened, since $\mathrm{G} 1$ had $78 \%$ of its teams, on average, on "Elite" and "Continental Competition" groups. Regarding these numbers, G1 improvement may be related to the fact that the teams within this group occupy the highest league positions. Those are the teams capable to generate prizes and financially stronger sponsors, which allows better investments and performance, increasing the likelihood of winning tournaments. In this case, these information corroborate the literature (Anderson \& Sally, 2013; Soriano, 2013), since G1 was the group with the highest revenue and best league positions. To ensure titles periodically, it is recommended to work with intensity to generate revenue and manage judiciously (Soriano, 2013). The literature also highlights the English football as an example of success that has a relevant impact on revenues (Dobson \& Goddard, 1998; Szymanski \& Smith, 1997), with national success being, in majority, driven by investments (Kuypers \& Szymanski, 1999; Szymanski \& Smith, 1997). Private investors tend to have superior resources and are becoming important to maintain the success in elite football (Kuper, 1999; Rohde \& Breuer, 2016b; Scelles, Helleu, Durand, \& Bonnal, 2016), what can also be related to the results found in this study. Moreover, the results demonstrated that $\mathrm{G} 2$ obtained lower revenue than $\mathrm{G} 1$, but higher than $\mathrm{G} 3$ and also occupied, in majority, intermediary league positions (68,49\% of teams between "Continental Competition and "Neutral"). G2 has teams which can classify for a continental competition and also keep themselves on Brazilian's first division league, which suggests that their sources of revenue are at least regular and in enough quantity, which, in turn, does not make them able to compete with G1 teams, but allows them to reach more modest objectives, like qualify to a continental competition and keep themselves on the highest division. Anderson \& Sally (2013) reinforce this point by saying that do not drop of the division, represents ensured money (close to 45 million of euros) for British clubs, being the biggest differential between medium teams in the first and second division league. In order to get enough resources, the literature gives some possibilities that might help to explain these results, as the use of strategies to accumulate financial resources like to be based on owning a global brand powerful to generate revenues from broadcasting, merchandising and ticketing (Gladden \& Milne, 1999; 
Pawlowski \& Anders, 2012) and the "sugar daddies", attracting private majority investors to apply money into the team (Franck, 2010; Kuper, 1999; Rohde \& Breuer, 2016a). G3 results point out that it is the group with the lowest revenue of all of the evaluated groups and those significant differences are only between the extremes. In other words, there were not significant differences among years in a row. The absence of significant differences among them may be related to the competence with $\mathrm{G} 1$ and $\mathrm{G} 2$, since those groups have higher media and commercial preference than G3, which might have allowed more collection and qualified investments, which, in turn, may not be a part of G3 teams reality, which teams would need to work hard with less resources to maintain themselves on first division. In addition, Kuper and Szymanski (2014) say that football is like a war, because those with less chances try to fight harder, while best teams can face big contexts more prepared. Added to this, the results demonstrated that G3 was the group with more troubles to get the best positions on league table, having, on average, their teams occupying the last positions and, in $80 \%$ of the cases, playing on second division (50\% of G3 teams). These results reinforce the literature data, demonstrating that clubs with the lowest revenues are also the ones with the worst league positions (Anderson \& Sally, 2013; Soriano, 2013). This information transmit a tendency that the highest revenue are related, in majority, to a higher likelihood of getting best positions on league table, while lowest revenues are more related to seasons connected with failure. The results are pertinent, since the richer the club is, the better will be the quality it will be allowed to bring to its team and higher goals would be determined, besides using even more the marketing effects (Kuper \& Szymanski, 2014). To that, Tomkins, Riley and Fulcher (2010) bring once more the Premier League as an example, since from 2002 to 2010 the teams with the most expensive line-up won the title in $66 \%$ of the cases. Anderson \& Sally (2013) also remember that to invest less is dangerous because that increases the chance of relegation, corroborating the results of this study and so, helping to explain G3 results, that had the worst results related with the lowest revenue. The author also remembers the British club Wigan, which from 2008 and 2012, got a $98 \%$ likelihood of relegation, having a payroll 4 times less than the Manchester United's one, corroborating once more this research results. Moreover, according to Rohde \& Breuer (2016a), revenue can also have an impact on teams performance, since the top 30 European revenue-generating football clubs have grown 7,9\% per year, top ten clubs have grown $9,5 \%$ per year and top five clubs have grown $11,7 \%$ per year, while bottom 15 clubs have grown $4,3 \%$ per year, bottom ten clubs have grown $4 \%$ per year and bottom five clubs have grown 3,8\% per year. Besides, G1 did not show significant difference on league table from 2007 to 2016, which demonstrates that $\mathrm{G} 1$ clubs, on average, have always been in the best league table positions. So, presenting higher revenue may allow teams to invest better, which can contribute to get even better positions, like it is pointed in the 
analysis. Moreover, Kuper and Szymanski (2014) bring the Lyon's (French team) President as an example, because he has said that the better the team players are, besides winning more matches, more supporters will be attracted, something that allows having the best team related to its own made investment. Moreover, it is seen that clubs compete by investments into an overinvestment scenario, what results in a dissipation of overall league revenues (Dietl, Franck, \& Lang, 2008). So, from 2004 to 2013, 90\% of national league titles were won by the top 30 elite football clubs in Europe and $88 \%$ were half finalists in the UEFA Champions League (Rohde \& Breuer, 2016b). With the aforementioned in mind, the fact that G2 and G3 do not present significant intragroup differences may be related to the $\mathrm{G} 1$ team's power, since G1 was the group capable to collect more resources. The most valuable resources represent, in fact, a better chance to be a champion and to occupy the highest positions on league table, thus attracting further better sources of revenue. Even with an imbalanced scenario for G2 and G3, Soriano's (2013) point represent a good suggestion, since it implies that keeping the performance and the wages well balanced, leaves a space to grow in future, which is an important attribute to reach higher goals at the right time. Financial resources have been demonstrated themselves as a relevant resource in amateur and professional football (Gerrard, 2005; Wicker \& Breuer, 2011), as well private investors have been argued to have superior conditions to invest in teams compared to clubs with dispersed ownership or owned by member associations (Franck, 2010). Regarding the correlation between revenue and league table position, the results pointed to strong correlations appearing in $\mathrm{G} 1$ and $\mathrm{G} 3$. In other words, G1 had powerful influence by the revenues to obtain the first positions on league table. On the other hand, G3 suffered from the influence of low revenue, occupying the lowest league positions. Those findings demonstrate that there is a possible correlation between revenue and clubs league table positions. On this study there was no confirmation of correlation appearing in G2, which can be explained by G2's oscillation on league table caused by having a lower revenue than $\mathrm{G} 1$, that might have compromised signing the contracts with the most qualified players. Considering the aforementioned, the reality of $\mathrm{G} 2$ is that the clubs in this group need to adapt themselves to compete with the big clubs. Concerning this matter, Soriano (2013) remembers that the biggest problem is not getting the best positions, but maintaining one, or maintain the same level, considering the dependence of sacrifice on demands. Corroborating to our results, authors collaborate saying that richer clubs are peculiar due to their higher growth rates and revenues, also dominating performance in national and continental scenarios (Rohde \& Breuer, 2016b), since teams investments exceeds profit-maximizing levels through evolutionary strategies to maintain themselves in the elite (Grossmann, 2015). Finally, regarding G3, besides having less resource than G1 and G2, which hinders G3's rise on league table, the group can also suffer with the football's 
urgency and the constant coach dismissals. These points are really present on Brazilian football and they also can hinder some team's progression for the lack of patience and time. In addition, Kuper \& Szymanski (2014) mention Arthur Hopcraft, author of the book "The Football Man", who said that football's first characteristic is that it is always urgent. The authors remember that media and supporters are always annoying the club to fire a particular coach or sign a particular player when things do not go well, which causes the club's irrational decision making caused by a financial point of view. The results of this study suggest that the irrational football club's dynamics, conducted by the immediately made decisions, may interfere in the work sequence, which can be an enormous issue to the clubs with the lowest revenues, since such dynamics restrict the squad to establish adequate conditions needed to achieve positive results. Moreover, less resources can decrease performance levels from G3, since the literature brings that, in Europe, from 2004 to 2013, the last non-top 30 club to win the Champions League was FC Porto in 2004, and to reach the semifinal was the Spanish Villarreal in 2006 (Rohde \& Breuer, 2016a), what shows that is hard to compete with less financial conditions.

\section{Conclusion}

Since the main objective of this study consisted in investigating the relation between revenues and league table position of Brazilian football clubs in the first division, it can be concluded that there is a relation between revenue and league table position, considering the results of this study. Moreover, the fact that G1 teams are able to collect more resources from sponsors and TV, besides being able to attract the interest of more qualified players to join the squad and to establish the institution's image, through marketing, makes it easier for G1 teams to collect more money, which is something that G3 teams might not be able approach in the same way. Confirming one of the hypothesis, teams with highest revenue demonstrated the best league table positions, through collecting more resources, they tend to have the best conditions to compete for the title and keep improving their revenue, not only through prizes and sponsors, but also through exploitation of their products using the marketing. The fact that G2 teams, even with increasing the revenue, did not achieve better league table positions is connected with the predictable G1 hegemony, since G1 teams have the highest revenue. It is hard to compete against the strongest teams because the difference of collections obtained and investments made is high, which causes imbalances when the performance is compared during the season. Regarding G3, the hypothesis was also confirmed: clubs with lower revenue tend to be in the last positions on league table, being really susceptible to suffer from relegation. It is evident that the available resources to this group are lower, which does not 
put them in a condition to bring the best footballers to their squads, obligating them to adapt themselves frequently to the demands. However, there is an important point that might cause troubles to all groups, but mainly to G3: football's urgency. Since in Brazil it is common that the coaches are fired after a short sequence of bad results, caused by the acceptance of media and supporter's pressure by the directors, the job is always interrupted, which may not provide the squad with an adequate condition to react to a bad moment, owing to the changes of ideas concerning the play and the changes of the level of knowledge about the players. Regarding the aforementioned, a development of new studies to be conducted in Brazil is suggested, with the intention to verify how these changes of coaches affect team's performance, besides getting more knowledge about the effects of investments made on football departments and it's relation with the performance throughout the seasons.

\section{References}

Amira, E., \& Livne, G. (2005). Accounting, Valuation and Duration of Football Player Contracts. Journal of Business Finance \& Accounting, 32(3-4), 549-586.

Anderson, C., \& Sally, D. (2013). Os números do jogo: por que tudo o que você sabe sobre futebol está errado. São Paulo: Paralela.

Barajas, A., Fernández-Jardón, C., \& Liz, C. (2005). Does sports performance influence revenues and economic results in Spanish football? MPRA Paper No. 3234. Retrieved December 4, 2012, from http://mpra.ub.uni-muenchen.de/3234/

Barros, C. P., Garcia-del-Barrio, P., \& Leanch, S. (2009). Analysing the Technical Efficiency of the Spanish Football League First Division with a Random Frontier Model. Applied Economics, 41(25), 3239-3247.

Barros, D. (2017). Clubes têm receitas recorde em 2016, mas consultor avisa: "2017 será ano da verdade." Globoesporte.com. Retrieved July 5, 2017, from http://globoesporte.globo.com/futebol/noticia/clubes-tem-receitas-recorde-em2016-mas-consultor-avisa-2017-sera-ano-da-verdade.ghtml

BDO, A. I. (2012). Finanças dos clubes de futebol do Brasil em 2011. Retrieved July 15, 2017, from http://www.estadao.com.br/especiais/2012/05/financas clubes.pdf

Borré, L., \& Gelmini, L. (2008). Goodwill, Negative Margins and Results: Some Evidence from the Professional Football Industry. In Eighth International Business Research Conference: Research For Change. Dubai.

Corinthians lidera ranking de receitas de 2010; Galo é o maior devedor. (2011). Globoesporte.com. Retrieved July 5, 2017, from http://globoesporte.globo.com/futebol/noticia/2011/05/corinthians-lidera-rankingde-receitas-de-2010-galo-e-o-maior-devedor.html

Dietl, H. M., Franck, E., \& Lang, M. (2008). Overinvestment in team sports leagues: $A$ contest theory model. Scottish Journal of Political Economy, 55(3), 353-368.

Dívidas, patrocínios e TV: veja os rankings das finanças dos clubes brasileiros em 2015. (2016). Espn.com.br. Retrieved July 5, 2017, from http://espn.uol.com.br/noticia/596431_dividas-patrocinios-e-tv-veja-os-rankings- 
Tertuliano W.I., et. al.: Do financial results influence sports results in football industry?

das-financas-dos-clubes-brasileiros-em-2015

Dobson, S. M., \& Goddard, J. A. (1998). Performance and revenue in professional league football: evidence from Granger causality tests. Applied Economics, 30(12), 1641-1651.

Espitia-Escuer, M., \& García-Cebrián, L. I. (2010). Measurement of the efficiency of football teams in the Champions League. Managerial and Decision Economics, 31(6), 373-386.

Field, A. (2009). Descobrindo a estatística usando o SPSS. São Paulo: Bookman.

Filipović, S., \& Miljković, M. (2014). Transition economies during global economic crisis: A difference in differences approach. Industrija, 42(3), 23-39.

Franck, E. (2010). Private firm, public corporation or member's association governance structures in European football. International Journal of Sport Finance, 5(2), 108.

Gerrard, B. (2005). A resource-utilization model of organizational efficiency in professional sports teams. Journal of Sport Management, 19(2), 143-169.

Gladden, J. M., \& Milne, G. R. (1999). Examining the Importance of Brand Equity in Professional Sport. Sport Marketing Quarterly, 8, 21-30.

Gonçalves, E. (2012). 13 Clubes de maior receita faturam quase 2 bilhões de reais em 2011. Globoesporte.com.. Retrieved July 5, 2017, from http://globoesporte.globo.com/platb/olharcronicoesportivo/2012/05/14/13-clubesde-maior-receita-faturam-quase-2-bilhoes-de-reais-em-2011/

Green, S. B., Salkind, N. J., \& Akey, T. M. (2000). Using SPSS for windows: analyzing and understanding data (2nd ed.). New Jersey: Prentice Hall.

Grossmann, M. (2015). Evolutionarily Stable Strategies in Sports Contests. Journal of Sports Economics, 16(1), 108-121.

Guzmán, I. (2006). Measuring Efficiency and Sustainable Growth in Spanish Football Teams. European Sport Management Quarterly, 6(3), 267-287.

Haas, D., Kocher, M. G., \& Slitter, M. (2004). Measuring Efficiency of German Football Teams by Data Envelopment Analysis. Central European Journal of Operations Research, 12, 251-268.

Jardin, M. (2009). Efficiency of French football clubs and its dynamics. Munich Personal RePEc Archive Paper No. 19828. Retrieved July 16, 2012, from http://mpra.ub.uni-muenchen.de/19828/

Kuper, S. (1999). How to be an elite club?-and will the losers go bust and disappear? Roundtable: "Perspectives and Economic Challenges for Elite Football Clubs." Retrieved August 14, 2014, from http://www.iese.edu/en/ad/spsp/armandcarabnworkshoponfootballeconomics.asp

Kuper, S., \& Szymanski, S. (2014). Soccernomics: Why England Loses, Why Spain, Germany, and Brazil Win, and Why the US, Japan, Australia - and Even Iraq Are Destinated to Become the Kings of the World's Most Popular Sport. New York: Nation Books.

Kuypers, T., \& Szymanski, S. (1999). Winners and Losers - the Business Strategy of Football. London: Viking.

Lakatos, E. M., \& Marconi, M. A. (2011). Metodologia Científica (6th ed.). São Paulo: Atlas.

Mará, M. (2015). Fla lidera ranking de receitas e é único dos grandes a reduzir dívida. Globoesporte.com. Retrieved July 5, 2017, from http://globoesporte.globo.com/futebol/noticia/2015/05/fla-lidera-ranking-dereceitas-e-e-unico-dos-grandes-reduzir-divida-veja-lista.html

Mijatović, P., Pavlović, V., \& Mllačić, S. (2015). Effect of investment on financial and 
Tertuliano W.I., et. al.: Do financial results influence sports results in football industry?

sports results. Industrija, 43(2), 143-165.

Morrow, S. (1999). The new business of football: Accountability and finance in football. London: Macmillan Business.

Pavlović, V., Ljumović, I., \& Knežević, G. (2014). Specifičnosti vrednovanja ljudskih resursa $u$ fudbalskoj industriji [Specificities of $\mathrm{hr}$ evaluation in the football industry]. Poslovna Ekonomija, 8(2), 223-238.

Pavlović, V., Mijatović, P., \& Mllačić, S. (2013). Financial Reporting of Football Clubs in R. Serbia. Management - Journal for Theory and Practice Management, 18(67), 55-62.

Pavlović, V., Milačić, S., \& Ljumović, I. (2014). Controversies about accounting treatment of transfer fee in football industry. Management - Journal for Theory and Practice Management, 19(70), 17-24.

Pawlowski, T., \& Anders, C. (2012). Stadium attendance in German professional football - The (un) importance of uncertainty of outcome reconsidered. Applied Economics Letters, 19(16), 1553-1556.

Pyatunin, A., Vishnyakova, A., Sherstneva, N., Mironova, S., Dneprov, S., \& Grabozdin, Y. (2016). The Economic Efficiency of European Football Clubs Data Envelopment Analysis (DEA) Approach. International Journal of Environmental and Science Education, 11(15), 7515-7534.

Ribeiro, A. S., \& Lima, F. (2012). Portuguese football league efficiency and players wages. Applied Economics Letters, 19, 599-602.

Rohde, M., \& Breuer, C. (2016a). Europe's Elite Football: Financial Growth, Sporting Success, Transfer Investment, and Private Majority Investors. International Journal of Financial Studies, 4(2), 12.

Rohde, M., \& Breuer, C. (2016b). The Financial Impact of (Foreign) Private Investors on Team Investments and Profits in Professional Football: Empirical Evidence from the Premier League. Applied Economics and Finance, 3(2), 243-255.

Rowbottom, N. (2002). he application of intangible asset accounting and discretionary Policy choices in the UK football industry. British Accounting Review, 34(4), 335-356.

Samagaio, A., Couto, E., \& Caiado, J. (2009). Sporting, financial and stock market performance in English football: an empirical analysis of structural relationships. CEMAPRE Working Papers. Retrieved December 25, 2012, from http://ideas.repec.org/p/cma/wpaper/0906.html

Scelles, N., Helleu, B., Durand, C., \& Bonnal, L. (2016). Professional Sports Firm Values: Bringing New Determinants to the Foreground? A Study of European Soccer, 2005-2013. Journal of Sports Economics, 17(7), 688-715.

Soleimani-Damaneh, J., Hamidi, M., \& Sajadi, N. (2011). Evaluating the performance of Iranian football teams utilizing linear programming. American Journal of Operations Research, 1(1), 65-72.

Somoggi, A. (2017a). Clubes brasileiros estão completamente dependentes da TV. Lance.com.br. Retrieved July 5, 2017, from http://blogs.lance.com.br/somoggi/clubes-brasileiros-estao-completamentedependentes-da-tv/

Somoggi, A. (2017b). Entendendo as finanças dos clubes brasileiros em 2016. Lance.com.br. Retrieved July 5, 2017, from http://blogs.lance.com.br/somoggi/entendendo-as-financas-dos-clubesbrasileiros-em-2016/

Somoggi, A. (2017c). Finanças dos clubes brasileiros em 2016: o ano da 
Tertuliano W.I., et. al.: Do financial results influence sports results in football industry?

hiperdependência da TV. Slidesahre.net. Retrieved July 5, 2017, from https://pt.slideshare.net/AmirSomoggi/finanas-dos-clubes-brasileiros-em-2016maio-de-2017-amir-somoggi

Soriano, F. (2013). A bola não entra por acaso. São Paulo: Larousse.

Szymanski, S., \& Smith, R. (1997). The English Football Industry: profit, performance and insdustrial structure. International Review of Applied Economics, 11(1), 135-153.

Tomkins, P., Riley, G., \& Fulcher, G. (2010). Pay as You Play: The True Price of Success in the Premier League Era. Wingston: Gprf Publishing.

Venancio, P. (2014). São Paulo supera Corinthians e tem a maior receita entre os clubes em 2013. Globoesporte.com. Retrieved July 5, 2017, from http://globoesporte.globo.com/futebol/noticia/2014/05/sao-paulo-superacorinthians-e-tem-maior-receita-entre-os-clubes-em-2013.html

Wicker, P., \& Breuer, C. (2011). Scarcity of resources in German non-profit sport clubs. Sport Management Review, 14(2), 188-201. 